\title{
PERBEDAAN STATUS GIZI ANTARA BAYI YANG DIBERI ASI DENGAN BAYI YANG DIBERI PASI PADA BAYI KURANG DARI 6 BULAN DI DESA KATEGUHAN KECAMATAN SAWIT
}

\author{
Oleh : \\ Rahayu Setyaningsih ${ }^{1}$ Tri Susilowati ${ }^{2}$
}

\begin{abstract}
Background. Mother's Milk is the first natural food for infants and should be given without any extra food to infants in 6 months. But today there are many parents who provide complementary feeding earlier less than 6 months. Both of these circumstances affect the nutritional status of infants.

The purpose of the study was to determine differences in the nutritional status of infants breast-fed infants fed with infants complementary feeding in the village Kateguhan Sawit subdistrict.

Methods comparative descriptive research design using cross sectional approach, the population consists of infants aged less than 6 months the total number were 39 infants, the sampling technique is total sampling, tdata analyzed using Mann Whitney U Test.

The conclusion the results of the nutritional status of infants exclusively breastfed most normal nutritional status of as many as 14 infants $(93.3 \%)$ while the infants with complementary feeding largely nourished baby fat as many as 15 infants (62.5\%). There are significant differences between the nutritional status of infants fed breast milk and complementary feeding ( $p$ value 0,000 $<0,05)$
\end{abstract}

Keywords : mother's milk, complementary feeding, nutritional status

\section{PENDAHULUAN}

Saat ini banyak sekali kita jumpai berbagai masalah kesehatan terutama masalah gizi. Menurut Riset Kesehatan Dasar (2010) prevalensi gizi kurang pada tahun 2010 menurun menjadi 17,9\%, yaitu ada 900 ribu diantara 2,2 juta balita di Indonesia mengalami gizi kurang atau gizi buruk. Indonesia termasuk diantara 36 negara di dunia yang memberi $90 \%$ kontribusi masalah gizi dunia. Saat ini Indonesia menduduki peringkat kelima dalam status gizi buruk. Status ini merupakan akibat instabilitas pangan karena kurangnya nilai gizi dalam konsumsi bayinya. Status gizi dipengaruhi oleh beberapa faktor yang meliputi penyakit infeksi, konsumsi makanan, sanitasi lingkungan dan pengaruh budaya. Terjadinya rawan gizi pada bayi disebabkan antara lain oleh karena ASI banyak diganti oleh susu formula dengan jumlah dan cara yang tidak sesuai kebutuhan. Menurut Yuliarti, 2010 ASI merupakan pilihan terbaik bagi bayi karena di dalamnya mengandung antibodi dan lebih dari 100 jenis zat gizi seperti $A A, D H A$, taurin dan spingomyelin yang tidak terdapat di dalam susu formula. Anak-anak yang tidak diberi ASI secara eksklusif sangat rentan terkena penyakit kronis seperti kanker, jantung hipertensi, dan diabetes setelah ia dewasa nanti. Tidak hanya itu, anak juga dapat menderita kekurangan gizi dan mengalami obesitas. Keadaan gizi 
kurang yang banyak ditemukan pada bayi-bayi terlihat ketika para ibu di daerah perkotaan memilih untuk menggunakan susu formula sebagai pengganti ASI.

Pemberian ASI eksklusif mempengaruhi status gizi bayi. Bayi akan baik dan mencapai pertumbuhan yang sesuai dengan usianya namun, disisi lain sering juga bayi yang diberi susu formula mengalami kurang gizi. ASI mengandung whey-casein lebih banyak yaitu 65:35, komposisi ini menyebabkan protein ASI lebih mudah diserap, sedangkan susu sapi memiliki whey-casein dengan perbandingan 20:80 sehingga tidak mudah diserap. (Yuliarti, 2010)

Pemberian PASI terlalu dini atau dibawah usia 4 bulan juga dapat menyebabkan kenaikan berat badan yang terlalu cepat sehingga menjurus ke obesitas hal ini dikarenakan belum matangnya sistem pencernaan bayi. Obesitas merupakan keadaan patologis dengan terdapatnya penimbunan lemak yang berlebihan dari yang diperlukan fungsi tubuh. The American Academy of Pediatrics menganjurkan para ibu untuk menyusui sendiri bayinya, karena tidak ada susu formula yang dapat menyaingi air susu ibu, yang sangat cocok dengan kebutuhan bayi. (Kelly, 2002)

Studi pendahuluan yang dilakukan di Desa Kateguhan Kecamatan Sawit diperoleh data dari 10 bayi yang dilakukan penilaian status gizi, pada bayi yang diberikan ASI eksklusif yang diukur berat badannya terdapat 4 bayi status gizinya normal sedangkan 1 bayi status gizinya kurang. Sedangkan pada bayi yang diberi PASI dini terdapat 3 bayi status gizinya lebih, 1 bayi status gizinya kurang dan 1 bayi status gizinya normal.

Dari hasil studi di atas menyebutkan tentang keterkaitan antara pemberian ASI eksklusif dan PASI dini terhadap status gizi, maka dari itu peneliti tertarik melakukan penelitian tentang perbedaan status gizi antara bayi yang diberi ASI dan bayi yang diberi PASI pada bayi kurang dari 6 bulan.

\section{METODE PENELITIAN}

Penelitian ini merupakan penelitian descriptive comparative dengan pendekatan cross sectional untuk mengetahui perbedaan status gizi bayi yang diberi ASI eksklusif dengan bayi yang diberi PASI, dengan cara membandingkan berat badan menurut panjang badan pada seluruh bayi yang berumur kurang dari 6 bulan di Kecamatan Sawit sebanyak 39 bayi. Dalam penelitian ini peneliti menggunakan teknik sampling jenuh sehingga yang menjadi sampel adalah 39 bayi di Kecamatan Sawit tersebut.

\section{HASIL PENELITIAN}

Berdasarkan penelitian yang telah dilakukan mulai bulan April sampai Agustus 2013 didapatkan karakteristik responden berdasarkan umur, berat badan dan panjang badan adalah sebagai berikut :

Tabel 1. Analisis deskriptif berdasarkan umur, berat badan dan panjang badan bayi yang diberi ASI dengan bayi yang diberi PASI

\begin{tabular}{ccccccc}
\hline \multirow{2}{*}{ Var } & \multicolumn{3}{c}{ ASI } & \multicolumn{3}{c}{ PASI } \\
\cline { 2 - 7 } & \multirow{2}{*}{ Mean } & SD & $\begin{array}{c}\text { Min- } \\
\text { Max }\end{array}$ & Mean & SD & $\begin{array}{c}\text { Min- } \\
\text { Max }\end{array}$ \\
\hline BB & 9.13 & 1.33 & $6.1-$ & 11,40 & 1.3 & $8.4-$ \\
& & & 11.2 & & 5 & 13.5 \\
\hline TB & \multirow{2}{*}{70.33} & 4.03 & $62.0-$ & 73.30 & 14. & $81-$ \\
& & & 76.1 & & 40 & 84 \\
\hline
\end{tabular}

Hasil analisis didapatkan rata-rata berat badan bayi yang diberikan ASI adalah $9,13 \mathrm{~kg}$ dengan standar deviasi $1,33 \mathrm{~kg}$ dan berat badan kurang $6,1 \mathrm{~kg}$, berat badan lebih $11,2 \mathrm{~kg}$. Sedangkan pada bayi yang diberi PASI dini rata-rata berat badan adalah $11,40 \mathrm{~kg}$ dengan 
standar deviasi $1,35 \mathrm{~kg}$. Panjang badan bayi yang diberikan ASI ratarata adalah 70,33 dengan standar deviasi $4,03 \mathrm{~cm}$ dan panjan badan terendah $62,0 \mathrm{~cm}$ panjang badan tertinggi $76,1 \mathrm{~cm}$ sedangkan pada bayi yang diberi PASI dini rata-rata panjang badan adalah 73,30 dengan standar deviasi $14,40 \mathrm{~cm}$ panjang badan terendah $81 \mathrm{~cm}$ dan panjang badan tertinggi $84 \mathrm{~cm}$.

Tabel 2. Tabel Distribusi Frekuensi Responden Berdasarkan Status Gizi Bayi Yang Diberi ASI

\begin{tabular}{ccc}
\hline $\begin{array}{c}\text { Status } \\
\text { Gizi }\end{array}$ & $\mathbf{F}$ & $\%$ \\
\hline Kurang & 1 & 6,7 \\
Normal & 4 & 93,3 \\
\hline Jumlah & 15 & 100 \\
\hline
\end{tabular}

Dari data di atas menunjukkan bahwa hampir seluruhnya status gizi bayi yang diberi ASI eksklusif memiliki status gizi normal yaitu sejumlah 14 bayi $(93,3 \%)$ dan hanya 1 bayi $(6,7 \%)$ yang mengalami status gizi kurang.

Tabel 3. Tabel Distribusi Frekuensi Responden Berdasarkan Status Gizi Bayi Yang Diberi PASI

\begin{tabular}{ccc}
\hline $\begin{array}{c}\text { Status } \\
\text { Gizi }\end{array}$ & $\mathbf{F}$ & $\%$ \\
\hline Lebih & 15 & 62,5 \\
Normal & 9 & 37,5 \\
\hline Jumlah & 24 & 100 \\
\hline
\end{tabular}

Dari tabel di atas dapat diketahui bahwa sebagian besar status gizi bayi yang diberi PASI mempunyai status gizi lebih yaitu sejumlah 15 bayi $(62,5 \%)$ dan 9 bayi $(37,5 \%)$ mengalami status gizi normal.
Tabel 4. Analisa Bivariat Perbedaan Status Gizi Pada Bayi Yang Diberi ASI Eksklusif dan PASI

\begin{tabular}{ccccc}
\hline Kelp & $\mathbf{n}$ & Mean & $\mathbf{Z}$ & $\begin{array}{c}\mathbf{P} \\
\text { value }\end{array}$ \\
\cline { 1 - 3 } PASI & 24 & 15,13 & & \\
\cline { 1 - 3 } $\begin{array}{c}\text { ASI } \\
\text { eks }\end{array}$ & 15 & 27,80 & $-3,93$ & 0,001 \\
\hline
\end{tabular}

Hasil analisis data menggunakan Man Whitney test didapatkan $\mathrm{p}$ value 0,001 , dimana $0,01<0,05$ berarti ada perbedaan yang signifikan antara status gizi pada bayi yang diberi ASI dan PASI di Desa Kateguhan Kecamatan Sawit.

Dari hasil penelitian ini terlihat bahwa perbedaan bayi yang diberikan ASI eksklusif memiliki status gizi normal sedangkan bayi yang diberikan PASI memiliki status gizi lebih.

\section{PEMBAHASAN}

1. Status gizi bayi yang diberi ASI eksklusif di Desa Kateguhan Kecamatan Sawit

Dari hasil penelitian yang dilakukan didapatkan hasil bayi yang diberi ASI eksklusif sebanyak 15 bayi dengan status gizi normal sejumlah 14 bayi $(93,3 \%)$ dan 1 bayi $(6,7 \%)$ mengalami status gizi kurang. Disini terlihat bahwa bayi yang diberi ASI eksklusif memiliki status gizi normal karena pemberian ASI secara eksklusif akan mendukung pertumbuhan dan berat badan bayi, karena komposisi ASI sudah sesuai dengan kebutuhan bayi. Semakin banyak bayi mendapatkan ASI, maka semakin kecil kemungkinan bayi mengalami kegemukan di kemudian hari, ASI mengandung berbagai bahan makanan yang baik untuk bayi yaitu terdiri dari proporsi yang seimbang dan cukup semua kuantitas zat gizi 
yang diperlukan untuk kehidupan 6 bulan pertama. Kandungan gizi dalam ASI sudah sesuai dengan kebutuhan bayi selama 6 bulan pertama, sehingga bayi tidak perlu diberikan makanan tambahan lain sebelum usia bayi 6 bulan. Hal ini sesuai dengan pendapat yang dikemukakan oleh Barasi (2007), penyebab maslah nutrisi adalah asupan, pencernaan dan absorpsi serta metabolisme, asupan gizi yang dikonsumsi seperti halnya ASI, yang diberikan pada bayi sampai usia 6 bulan sehingga mengoptimalkan pertumbuhan dan perkembangannya. Komposisi yang terkandung di dalam ASI pun juga sesuai dengan kebutuhan seperti $88,1 \%$ air, 3,8\% lemak, 0,9\% protein, $7 \%$ laktosa serta $0,2 \%$ zat lainnya. Teori yang dikemukakan oleh Yuliarti, (2010) mendukung teori yang sebelumnya yang menyatakan bahwa gizi yang lengkap, jumlah volume dan komposisi ASI juga menyesuaikan dengan kebutuhan bayi, sehingga tidak perlu diberikan makanan tambahan sampai bayi berusia 6 bulan sehingga pemberian gizi yang cukup namun berkualitas akan mempengaruhi pertumbuhan dan perkembangan bayi.

Penelitian ini sesuai dengan hasil penelitian yang dilakukan oleh Setyoadi, (2010) di Puskesmas Junjerojo Kota Baru dengan jumlah populasi 30 bayi usia 0-6 bulan menggunakan uji statistik independen $t$ test bahwa bayi yang diberikan ASI secara eksklusif memiliki status gizi baik. Hal ini disebabkan karena ASI telah memenuhi kebutuhan bayi usia 0-6 bulan, ASI mengandung protein, lemak, mineral, air dan enzim yang sangat dibutuhkan oleh tubuh sehingga ASI akan mengurangi berbagai jenis kekurangan gizi.

Pada penelitian ini didapatkan hasil bahwa bayi yang diberikan ASI eksklusif ternyata didapatkan pula bayi yang status gizinya kurang. Hal ini disebabkan karena bayi mempunyai riwayat sering sakit, tetapi pada saat dilakukan penelitian bayi dalam keadaan sehat. Wantania, (2008) menyatakan bahwa penyebab gizi kurang tidak hanya karena makanan yang tidak sesuai, tetapi juga karena penyakit. Anak yang mendapat makanan yang baik tetapi sering sakit diare atau demam dapat menderita gizi kurang. Demikian juga dengan anak yang makanannya tidak cukup baik maka daya tahan tubuh makin melemah dan mudah terserang penyakit. Kenyataan secara bersama-sama baik makanan maupun penyakit merupakan penyebab gizi kurang.

2. Status gizi bayi yang diberi PASI di Desa Kateguhan Kecamatan Sawit

Dari hasil penelitian didapatkan hasil bayi yang diberikan PASI sebanyak 24 bayi. Status gizi bayi yang diberi PASI dengan kategori gemuk yaitu sejumlah 15 responden $(62,5 \%)$ dan 9 responden $(37,5 \%)$ yang mengalami status gizi normal.

Bayi yang mengalami status gizi lebih dikarenakan oleh pemenuhan gizi yang tidak seimbang menurut keadaan bayi. Pemberian susu formula serta makanan pendamping ASI cair yang diberikan pada bayi kurang dari 6 bulan cenderung dengan intensitas atau frekuensi yang sangat tinggi sehingga dapat membahayakan dan berakibat kurang baik pada anak yang dampaknya adalah kerusakan pada usus bayi, karena pada umur demikian usus belum siap 
mencerna dengan baik sehingga pertumbuhan berat badan bayi terganggu antara lain adalah kenaikan berat badan yang terlalu cepat sehingga mengarah pada kegemukan.

Bayi yang lebih dini diperkenalkan pada PASI akan cenderung memiliki pola makan yang tidak sesuai dengan tubuhnya. Bayi akan terbiasa dengan makan banyak atau berlebihan. Inilah yang membuat bayi beresiko menjadi gemuk atau obesitas. Pemberian PASI saat bayi kurang dari 6 bulan dapat dipengaruhi dari kesibukan orangtua yang bekerja di pabrik dan juga karena kurangnya pengetahuan masyarakat tentang usia pertama pemberian makanan pendamping ASI, sehingga kebanyakan ibu memberikan PASI kurang dari 6 bulan. Makanan pendamping ASI (PASI) merupakan makanan atau minuman yang mengandung gizi yang diberikan pada bayi atau anak berumur 6-24 bulan untuk memenuhi kebutuhan gizinya. Apabila PASI diberikan kurang dari 6 bulan yang berarti terlalu dini akan berdampak pada terjadinya tumbuh kembang dan beresiko obesitas. (Depkes, 2006)

Penelitian ini sesuai dengan hasil penelitian yang dilakukan oleh Sari, (2011) yang menunjukkan pengenalan PASI sebelum bayi berusia 6 bulan menyebabkan bayi lebih sering mengalami masalah kesehatan seperti infeksi dan mengalami obesitas. Hal ini disebabkan pemberian ASI saja mampu memenuhi kebutuhan gizi bayi sampai usia 6 bulan tanpa pemberian makanan tambahan. Itulah sebabnya makanan pendamping ASI diberikan kepada bayi saat berusia 6 bulan.
3. Perbedaan status gizi antara bayi yang diberi ASI eksklusif dengan bayi yang diberi PASI pada bayi usia kurang dari 6 Bulan

Berdasarkan uji statistik Mann Whitney Test menunjukkan $\mathrm{p}$ value 0,001 lebih kecil dari 0,05 , sehingga didapatkan kesimpulan bahwa terdapat perbedaan yang signifikan antara status gizi pada bayi yang diberi ASI eksklusif dan bayi yang diberi PASI. Bayi yang diberikan ASI eksklusif memiliki status gizi normal daripada bayi yang diberikan PASI lebih dini yang memiliki status gizi lebih. ASI eksklusif tidak hanya untuk status gizi, tetapi menghindari kegemukan di masa yang akan datang karena kegemukan akan menyebabkan penyakit diabetes melitus, hipertensi, jantung dan penyakit degeneratif lainnya. Disamping itu bayi yang mendapatkan ASI eksklusif lebih baik pertumbuhannya, memiliki kecerdasan yang tinggi dan daya tahan tubuh yang lebih baik, meskipun berat badan tidak mengalami kenaikan atau stabil. Asupan protein sehari pada bayi yang diberikan PASI lebih tinggi daripada ASI eksklusif, asupan ptotein yang melebihi kebutuhan sisanya akan dibuang melalui ginjal. Keadaan seperti ini akan memperberat kerja ginjal. Belum lagi bayi yang mendapatkan susu formula terlalu pekat yang akan membuat bayi haus sehingga akan memicu bayi minum susu lebih banyak. Keadaan ini akan menambah protein lebih banyak. Seorang bayi yang menyusu cenderung mengkonsumsi ASI sesuai dengan kebutuhannya. Pemberian makanan pendamping yang terlalu dini pada bayi cenderung terjadi peningkatan berat badan lebih, hal ini dikarenakan bayi mendapatkan asupan gizi dari sumber makanan 
lain seperti susu formula, air teh, pisang atau makanan cair lain seperti air gula, teh, bubur nasi atau nasi tim. Menurut Supariasa, (2002) keadaan kesehatan akan baik jika keseimbangan antara konsumsi dan kebutuhan zat gizi terjamin maka berat badan akan berkembang menurut usia.

Penelitian ini sesuai dengan hasil penelitian yang dilakukan oleh Haris, (2011) di RSUD Al-Ihsan Jawa Barat dengan populasi bayi usia 0-6 bulan berjumlah 42 bayi. Terdapat perbedaan yang signifikan pemberian ASI eksklusif dan bayi yang diberikan PASI. Bayi yang diberikan ASI eksklusif menunjukkan perubahan berat badan bayi yang stabil dengan status gizi baik. Sedangkan pada bayi yang diberikan PASI perubahan berat badan besar dengan status gizi lebih. Bayi yang lebih dini diperkenalkan pada PASI akan cenderung memiliki pola makan yang tidak sesuai dengan tubuhnya, bayi akan terbiasa dengan makan banyak atau berlebihan, inilah yang membuat bayi menjadi gemuk. Hal ini sesuai dengan penelitian Sri, (2013) yang menyatakan pengenalan PASI dini pada bayi menyebabkan beresiko gemuk atau obesitas karena asupan gizi yang berlebihan.

\section{KESIMPULAN DAN SARAN}

1. Kesimpulan

a. Status gizi bayi yang diberi ASI eksklusif didapatkan bayi dengan status gizi normal sebanyak 14 bayi $(93,3 \%)$.

b. Status gizi bayi yang diberikan PASI didapatkan bayi dengan status gizi lebih sebanyak 15 bayi $(62,5 \%)$.

c. Ada perbedaan yang signifikan pada status gizi bayi yang diberikan ASI eksklusif dan PASI.
2. Saran

a. Bagi tenaga kesehatan

Dalam rangka mencapai keberhasilan gerakan

nasional pemberian ASI eksklusif maka perlu dilakukan peningkatan sosialisasi dan penyuluhan tentang ASI eksklusif lebih lengkap dan bertahap kepada masyarakat tidak hanya tenaga kesehatan tetapi juga kader kesehatan sehingga bisa meningkatkan pengetahuan masyarakat.

b. Bagi orangtua

Disarankan agar para ibu tetap memberikan ASI secara eksklusif sampai usia 6 bulan, karena ASI merupakan makanan yang ideal bagi bayi dan pemberian PASI terlalu dini akan menyebabkan kegemukan pada bayi, hal ini tidak baik bagi bayi karena kegemukan merupakan keadaan patologis dengan terdapatnya penimbunan lemak yang berlebihan dari yang diperlukan oleh tubuh.

\section{DAFTAR PUSTAKA}

Barasi, Mary E. At A Glance IImu Gizi. Jakarta: Erlangga, 2007.

Kelly, Paula, ed. Bayi Anda Tahun Pertama. Jakarta: Arcan, 2002.

Yuliarti, Nurheti. Keajaiban ASI Makanan Terbaik Untuk Kesehatan, Kecerdasan dan Kelincahan Si Kecil. Yogyakarta: ANDI, 2010.

Supariasa, dkk. Penilaian Status Gizi. Jakarta : EGC, 2002. 
Wantania, J.M.. Infeksi Respitory Akut. Buku Ajar Respirologi Anak Edisi Pertama. Jakarta : IDAI, 2008

Depkes RI. Pedoman Umum Pemberian Makanan Pendamping ASI (MP-ASI lokalP). Bersumber dari http;//,A-ww.depkes.org.ld. 2006.

Haris, S. Perbedaan Dampak Pemberian Nutrisi Asi Eksklusif dan Non Eksklusif Terhadap Perubahan Antropometri dan Status Imunitas Bayi. Di RSUD Al Ihsan Jawa Barat. (Tesis). Program Studi Magister Keperawatan. Universitas Indonesia, Depok. 2011.

Sri, W. Hubungan Usia Pertama Pemberian Makanan Pendamping ASI (MP-ASI) dengan Status Gizi Bayi Usia 0-12 Bulan di Kelurahan Karangjati Kecamatan Bergas Kabupaten Semarang.
Skripsi Ngudi Waluyo. 2013.

Sari, E. 2011. Hubungan Pola Pemberian MP-ASI dengan Status Gizi Bayi Usia 0-12 Bulan di Wilayah Pesisir kecamatan Tallo Kota Makasar. Bersumber dari :http://respitory.unhas.ac.id /handle/12345678/54810 diakses tanggal 2 Januari 2014

1 Dosen AKPER Panti Kosala Surakarta

2 Dosen AKPER Panti Kosala Surakarta 